\title{
Appendix 3: The final statement of the Special Rapporteur to the UN Human Rights Council
}


Statement of the Special Rapporteur on the Situation of Human Rights in Cambodia

\title{
Professor Surya Prasad SUBEDI
}

\author{
Human Rights Council \\ $27^{\text {th }}$ Session
}

24 September 2014 
Mr President, Excellencies, Ladies and Gentlemen,

I have the honour to address the Council to provide a brief account of the progress made and the challenges remaining in the promotion and protection of human rights in the Kingdom of Cambodia since I addressed it last year. I would like to begin by thanking the Royal Government of Cambodia and all my interlocutors for the general welcome and cooperation that I have received during the reporting period. I particularly commend the timely and substantive response that I have received from the Government to my communications and the cooperation that $\mathrm{I}$ have received from the Permanent Representative of Cambodia to the UN in Geneva, H.E. Mr Ney Samol, in my dealings with the Government. I also would like to thank the Office of the United Nations High Commissioner for Human Rights - both in Geneva and Cambodia - for the excellent support that I have received.

I have had the privilege of serving as the United National Special Rapporteur on the situation of human rights in Cambodia since May 2009 and will be completing my full term of six years in this position in March 2015. Therefore, this will be my last address to the Council in this capacity. I am pleased to state at the very outset that the situation in Cambodia has changed a great deal over this period. The leaders of the ruling party and the opposition struck a deal in July to end the political deadlock in the country. The Government has implemented some of my recommendations and has assured me that some others are in the process of being implemented. The country is currently in the process of peaceful political transition.

There were periods of despair when the leader of the opposition was in exile due to politically motivated charges, a prominent human rights activist and director of an independent radio station was imprisoned, there were attempts to silence dissent from many quarters, including through assassinations, and I myself was subjected to orchestrated harassment. But I remained persistent, objective, and impartial in the implementation of my mandate, which I continued to fulfill in a constructive manner and things began to take a turn for the better.

I had the support of the international community and the civil society organisations in the country. I am humbled by the overwhelming support I received particularly from the youth, many human rights defenders and the friends and well-wishers of Cambodia.

Owing to the endeavours of those fighting for human rights, including myself, the leader of the opposition was able to return to the country to participate in the political process, a 
number of leading human rights defenders were released from prison and the Government returned to a normal mode of cooperation with my mandate.

After a year protesting alleged electoral irregularities, opposition party members have now joined the National Assembly, both the ruling and the opposition party have agreed to press ahead with electoral reform and nominated a prominent female human rights activist to join the National Election Committee. I am encouraged by the acceptance of the rationale for electoral reform contained in my 2012 report by both parties. There is now a ray of hope that future elections might be freer and fairer than in the past; ensuring it will be so will require sustained efforts on electoral reforms.

The Human Rights Commission of the National Assembly has started to operate. Following the deal in July, the ban on demonstrations in Freedom Park, a symbol of democracy in Cambodia, was lifted in August 2014. With regard to the long overdue parliamentary reform, the presence of a healthy opposition makes it possible for Parliament to function as a credible and effective check on the executive. The work, however, has only now begun.

Regarding judicial reform, three long overdue fundamental laws were recently enacted and the election of four of the members of the Supreme Council of Magistracy, a body responsible for overall supervision of the judiciary, is taking place. I welcomed in principle their enactment, which constituted the core of the recommendations in my 2010 report. However, I was concerned by their untransparent and unparticipatory process of elaboration and adoption. I remain deeply concerned by certain provisions that compromise the independence of the judiciary and the doctrine of the separation of powers; I nevertheless believe that the laws provide a framework for improvement in the future, and I urge both parties to embark upon this task immediately. Other remarkable measures have been taken in the fields of education and public administration that demonstrate that Government-led reform is possible. The municipality of Phnom Penh, although not without its critics during the most politically sensitive moments, has been more open to collaborating with civil society than in the past.

We are also witnessing unprecedented events in the Extraordinary Chambers in the Courts of Cambodia, known as the Khmer Rouge Tribunal. The Tribunal has convicted two of the most senior leaders of the Pol Pot regime on charges of crimes against humanity. It is difficult for me to convey what this means to those who suffered atrocities at their hands. To the donors of the Tribunal, some of whom have understandably shown signs of fatigue, I wish to stress 
that your steadfast support is critical now, as the Tribunal advances on the most important crime of all: genocide.

Mr President,

That we should have reason for optimism must not be mistaken for actual progress in human rights protection. There have been political agreements in the past that were later only frustrated by the Government. It remains to be seen how sincerely and swiftly the promised reforms will be carried out. We must be mindful that the ruling party retains ultimate control over all three branches of the State: the executive, the legislature and the judiciary. In other words, the political environment may have changed but the fundamentals of governance and human rights protection have not.

As a result, the list of impunity cases is long and growing. Little has been done to bring perpetrators to justice, including those responsible for the repeated incidents since last September involving excessive use of force against protestors. In several incidents over the past year, scores of individuals were shot dead or injured. Many months later, we are no closer to identifying those responsible.

The peaceful transition now underway remains fragile. Many of the issues surrounding land rights remain unresolved and the people on the margins of society continue to suffer from serious violations of their rights. A renewed effort is underway to prosecute trade union leaders, at a crucial time when the minimum wage is being negotiated. Several draft laws are under elaboration that could restrict the operation of NGOs and trade unions and limit the free flow of information on the internet. As seen in its response to my report, the Government continues to deny that participation in these important legislative processes is a human right. A number of opposition members are still facing criminal charges, and just last week the ability of the opposition to summon or invite non-Parliamentarians to enter the Parliament's compounds was curtailed. The country clearly has a long way to go to fulfill its obligations under the international human rights treaties voluntarily ratified by it, including even on basic survival rights.

Without a doubt, the most significant change since July 2013 is that the Cambodian people have found their voice. This deserves to be celebrated. However, it is the implementation of meaningful reform that will demonstrate the tangible progress to the people of Cambodia, as well as the international community, necessary to show that Cambodia no longer needs this mandate. 
Accordingly, I submitted to this Council four substantive reports on judicial, parliamentary, electoral and land reform. I took a macro rather than micro approach and decided to focus my work on the overarching human rights issues. My latest and final report to the Council focuses on the independence of monitoring institutions and on the possibility of establishing a national human rights institution compliant with the Paris Principles. If I were to choose one recommendation as the sum of all others, it might be that the Government should reconsider its opposition to independent institutions. Taking concrete steps toward the establishment of an independent anti-corruption body, torture preventive mechanism, human rights institution, among many others that are needed would demonstrate that the path toward reform is irreversible. So would concrete guarantees to respect, in law and in practice, the independence of the judiciary, the National Election Committee, and Parliament itself. Cambodia is far from that point. The response to a dysfunctional conflict resolution mechanism should not be the creation of another, but the strengthening of the existing ones. Make them independent; otherwise, do not be surprised when social conflicts continue unabated.

Having said that, I reiterate my strong belief that Cambodia is on the cusp of historical changes. I refer not to the political arena but to the human rights protection infrastructure. Both the watchful eye and helping hand of the international community are critical now to keep the momentum headed in a positive direction. I will faithfully track the progress made during my next and final mission to the country in January 2015, the results of which will be reported to this Council by my successor.

Allow me to close, Mr. President, by thanking the Council for placing its trust and confidence in me by appointing me to this position in March 2009 and for renewing my mandate annually and then for two-year terms, which provided me the stability needed to follow a more strategic approach. It has been an immense privilege to have served this Council and the people of Cambodia. 